CHINESE FAMILY AND KINSHIP 


\section{CHINA IN FOCUS}

China has undergone rapid and dramatic changes over the past two decades. To the social scientist in Chinese Studies, this presents both a problem and a challenge. Not only does newly acquired information become quickly dated, but many basic assumptions about this country and her people have to be reexamined in the light of new evidence, and areas of research previously neglected have been given new impetus. This series, with many contributions from well-established sinologists, seeks to highlight the most recent developments in the People's Republic of China. It is hoped that the series will thus reflect the changing trend of analysis and give voice to new research findings. As far as possible, China will also be analysed within the general context of development studies.

Students in Chinese and development studies as well as comparative social sciences courses will find this series indispensable reading. It is our hope that we will also find an audience among interested general readers. Most of the titles will be published in both hardcover and a low priced paperback edition.

\section{Already published:}

Sartaj Aziz: Rural Development-Learning from China.

\section{In preparation:}

Gordon White and Peter Nolan: Equality and Development in the People's Republic of China. 


\title{
CHINESE FAMILY AND KINSHIP
}

\author{
DR HUGH D R BAKER \\ Lecturer, Department of the Far East, \\ School of Oriental and African Studies, \\ University of London
}


All rights reserved. No part of this publication may be reproduced or transmitted, in any form or by any means, without permission.

First published 1979 by

THE MACMILLAN PRESS LTD

London and Basingstoke

Associated companies in Delhi Dublin

Hong Kong Johannesburg Lagos Melbourne

New York Singapore and Tokyo

British Library Cataloguing in Publication Data

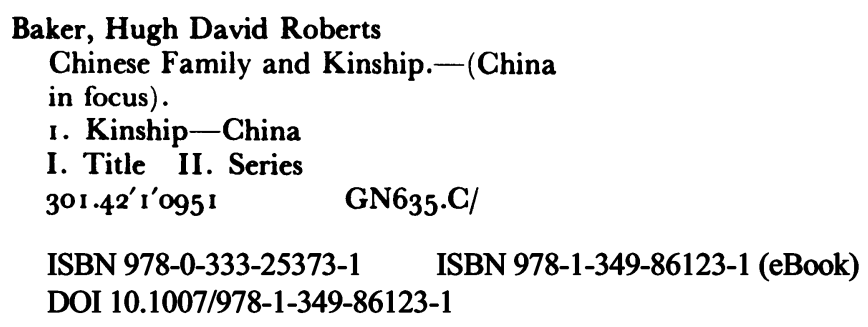

This book is sold subject to the standard conditions of the Net Book Agreement.

The paperback edition of this book is sold subject to the condition that it shall not, by way of trade or otherwise, be lent, resold, hired out, or otherwise circulated without the publisher's prior consent in any form of binding or cover other than that in which it is published and without a similar condition including this condition being imposed on the subsequent purchaser 
To my parents

B R B (JP) and Fairy

with love and gratitude 


\section{Contents}

Preface $\quad$ xi

I. THE COMPOSITION OF THE FAMILY I

The Ideal Family I

Simple, Stem and Extended Families 2

Poverty and Family Size Limitation 3

Pro and Con the Extended Family Io

Male versus Female $\quad 2$ I

2. THE INDIVIDUAL AND THE FAMILY 26

The Continuum of Descent $\quad 26$

Entering the Family $\quad 28$

Birthdays 3 I

Betrothal and Marriage $\quad 32$

The Aged and the Family Head 37

$\begin{array}{ll}\text { Death } & 39\end{array}$

The Woman and the Family 40

3. THE LINEAGE AND THE CLAN 49

The Lineage 49

The Lineage and the Ancestral Trust 50

Organization and Leadership of the Lineage $\quad 55$

The Lineage and the Village 64

The Higher-order Lineage and the Clan 67

4. ANCESTOR WORSHIP 7I

The Mutual Dependence of Ancestors and Descendants $7 \mathrm{I}$

$\begin{array}{ll}\text { Non-ancestors } & 74\end{array}$

Ancestor Worship for the Living $\quad 79$

Ancestor Worship and the Family $\quad 82$

Ancestor Worship and Larger Kin Groups $\quad 91$

Ancestor Worship and 'Chinese Religion' 97

Xiao $\quad 102$ 
5. THE FAMILY IN STATE AND SOCIETY 107

$\begin{array}{ll}\text { The } w u-f u & 107\end{array}$

The Family in the Law 113

Positive Sanctions Behind the Family 118

Family versus State $\quad$ I21

Family and Affines $\quad 124$

Family and Neighbours 130

Families in Competition 131

6. THE LINEAGE IN SOCIETY AND STATE I 6

The Lineage Territory $\quad{ }^{136}$

Inter-lineage Relationships $\quad 144$

Inter-lineage Hostility $\quad 146$

Lineage and State $\quad 152$

7. NON-KIN AS KIN 162

Terms of Address $\quad 162$

Quasi-kinship Organizations $\quad 164$

The State as a Family $\quad 167$

Kinship and the Overseas Chinese $\quad 169$

Kinship and Distance $\quad 173$

8. KINSHIP IN THE 2OTH GENTURY I

Milestones of Change $\quad$ I 76

The Composition of the Contemporary Family $\quad$ I89

The Individual and the Contemporary Family 192

The Fate of the Lineage $\quad 204$

Ancestor Worship in Contemporary China 206

The Family in Contemporary Society 211

The Family of the State $\quad 2$ I 3

Appendix I The Sacred Edict of the K'ang Hsi

Emperor $\quad 218$

Appendix II Feng-shui Fighting 219

Appendix III Anti-lineage Law and Statutes 226

$\begin{array}{ll}\text { Notes } & 229\end{array}$

List of Works Cited 234

Glossary $\quad 239$ 


\section{Table of Figures}

I. Generation-Age-Sex Hierarchy 16

2. Family Division 18

3. Second Generation Family 18

4. The Continuum of Descent 27

5. Cousin Marriage 43

6. Trust and Private Inheritance $5^{\mathrm{I}}$

7. Trust Distribution 54

8. Differentiated Generation Depth 57

9. Liao Lineage Segmentation 63

10. The $W u-f u$ (Mourning Grades) 108

I 1. Patrilineal Mourning Grades 109

12. Matrilineal Mourning Grades

13. Mourning for Married Out Females and their Children 1 I I

14. Married Woman's Mourning for her Natal Family 127

15. Married Woman's Mourning for her Husband's Family

16. Mourning for Wife's Natal Family 129

17. Lineage Territory 138

18. Liao Territory-First Abstraction 140

19. Liao Territory-Second Abstraction 140

20. Liao Territory-Third Abstraction $14^{1}$

21. A Lineage Landscape model $14^{2}$

22. Conflicting Alliances $\quad 145$ 


\section{Table of Maps}

I. Liao Territory

I 39

2. China (physical)

I 55

3. China (political)

I 55 


\section{Preface}

Kinship was not the only principle of social organization in traditional China, of course, but it was important enough to merit treatment as a full topic in its own right, and I have made no attempt to stray into other fields in this book. For the most part I talk in terms of 'traditional' China, which is a convenient shorthand for 'pre-twentieth century' China. For this reason I have used the past tense in all but the final chapter, sections of which pick up on the titles of previous chapters for ease of reference and comparison with the present.

Much of tradition is still evident in contemporary society, and especially so in Chinese communities outside the People's Republic. Tradition no more stopped dead in 1900 or I9I I than did modernity begin in 1912 or 1949. So, in trying to assess kinship in action I have been able to indulge unrepentantly in chronological sleight-of-hand, using twentieth-century fieldwork studies to illustrate features of the traditional scene, and using history to back up analysis of more recent times. This is not ideal, but material must be sought where it can be found.

Out of this has emerged, I hope, a clear picture of the family and its place in Chinese society. It is only a general picture, however, a basic account of the stock of kinship principles from which the Chinese could draw. I have dealt with rural China, barely mentioning the city, and I have not attempted to point the differences between areas of China or between the various Chinese sub-cultures. Nor have I gone into much detail on the 'mechanics' of family life - ceremonial, division of labour, childrearing, day-to-day living, and so on. For such details the reader may go to the many sources quoted in the book. I have used quotations freely: first, to show my debt to the ideas of others; and second, as a means of introducing all the major English-language writings on the Chinese family to the attention of the reader new to this field. The quotations in many cases serve to advance the argument of the text; they are not merely for confirmation of points already made. 
Despite the constant reference to other writings, this is my own idiosyncratic view of Chinese kinship. I am perhaps open to the criticism, for instance, that I have given too much space to discussion of the lineage: but it seems to me that the lineage brings most sharply into focus the major features of the system. Ancestor worship, too, occupies no small part of the book: again, I feel that the light it throws on kinship organization warrants such attention. It is my hope that with this book as a basis the reader may more readily understand the complexities of detail which he will meet as he goes on to look more deeply into the subject.

I have held mainly to English-language sources but, where Chinese sources have been used, the translations are my own unless otherwise stated. Chinese terms have been kept to a minimum. Romanization is in the official Chinese Pinyin system, except where another form is in conventional use (e.g. Mao Tse Tung). And of course I have not interfered with the romanizations used in direct quotations from other authors.

I should like to record my gratitude to Dr James L. Watson and Mrs Rubie S. Watson for their comments on four of the chapters; and to Mr Dick Wilson, editor of the China Quarterly, for his advice on Chapter 8. The late Professor Maurice Freedman read and criticized some of the early chapters. No-one working in the field of Chinese kinship can be out of his debt, myself least of all, for I owe gratitude for his teaching, his guidance, and his friendship too.

School of Oriental \& African Studies H.D.R.B. University of London.

October 1977. 